\title{
BEST PRACTICES OF CHURCH BUILDING BASED ON LOCAL WISDOM IN KENDARI CITY: A STUDY IN THE STASI ANDUONOHU OF CATHOLIC CHURCH
}

\author{
Muhammad Ali Saputra \\ Balai Penelitian dan Pengembangan Agama Makassar \\ Jl. A.P. Pettarani No. 72 Makassar, Indonesia \\ Email: alecbalitbang@gmail.com
}

Article received August $7^{\text {th }}, 2021$; Article revised September $20^{\text {th }}, 2021$; Article approved October $22^{\text {th }}, 2021$

\begin{abstract}
Although the Constitution has guaranteed the construction of places of worship in several areas, especially in the context of majority-minorities, it still faces many obstacles. The government issued PBM regulations No. 9 and 8 of 2006 to solve the problem of building houses of worship administratively, but often, in the conflict cases over the construction of places of worship, it does not provide the expected solution. This study tries to look at local wisdom as an alternative capital for best practice in constructing houses of worship in Kendari City. By taking the construction of the Anduonohu Stasi of Catholic Church as a case, the researchers found that the construction of the Anduonohu Stasi of Catholic Church proceeded peacefully. The church could fulfill the administrative requirements according to applicable regulations, without rejection from residents who were predominantly Muslim. In the construction of the church, although it is not explicitly said to be based on local wisdom, the construction of the Anduonohu Stasi of Catholic Church is supported by values/sense of responsibility, mutual respect, and love, as well as a willingness to sacrifice as shown by the residents around the church and other parties, and the church itself. The community around the church did not participate in providing financial or labor assistance. However, their willingness to accept a different place of worship in their environment by not making efforts to reject it. Meanwhile, from the government side, participation takes the form of granting permits, recommendations, and distributing aid. The limited-time in data collection requires further exploration regarding the best practice for the church's construction and the local wisdom of the residents around the environment.
\end{abstract}

Keywords: tolerance, best practice, church building, local wisdom

\section{INTRODUCTION}

I ndonesia is known as the country with the largest Muslim population in the world. However, Islam is not the only religion in Indonesia. There are still other recognized religions in Indonesia, namely Christianity, Catholicism, Hinduism, Buddhism, and Confucianism. These religions also spread throughout Indonesia. Although Islam is the majority religion in Indonesia, several areas are dominated by other religions. Bali Island for Hinduism, North Sulawesi, Maluku and Papua for Christianity, and NTT for Catholicism.

All religious people have the right to do their worship activities regarding their respective religions and beliefs, according to Article 29 of the 1945 Constitution. It also means that they have the right to build their places of worship. In reality, many religious adherents find difficulties to build a place of worship in their neighborhood, let alone to worship. Such conditions are often encountered by residents who are adherents of minority religions who live in the environment of the majority religion. The residents of religious minorities want to build a place of worship in the area, for example, the case of the GKI Yasmin house of worship in Bogor in 2008 and HKBP Fidelia in Bekasi. Not only places of worship for Christians, but the same has also happened to the construction of places of worship for Muslims in several areas in Eastern Indonesia, such as Manado, Kupang in NTT, Manokwari in West Papua, and Sentani in Papua.

As quoted by voaindonesia.com, during 2017-2019, Komnas HAM received 23 reports of violations of religious freedom, particularly regarding places of worship. Cases of houses of worship occurred in East 
Nusa Tenggara, East Java, West Java, Southeast Maluku, and North Sulawesi. These cases include the sealing of houses of worship, issues of building permits or Izin Mendirikan Bangunan (IMB), to burning and attacks on houses of worship. These cases relate to the Joint Regulations of the Minister of Religion and the Ministry of Home Affairs (PBM) Numbers 9 and 8 of 2006, which regulates the establishment of houses of worship. These cases will trigger a wider conflict in society if not handled properly by the government. Komnas HAM researcher, Agus Suntoro, added that it is difficult for religious people to meet the requirements in establishing a house of worship, especially regarding the list of houses of worship's users of at least 90 people and local community support of at least 60 people. In addition, religious people are sometimes hampered in obtaining an IMB (Building Permit) even though they have met the requirements (Madrim, 2020).

Anticipating the weaknesses of PBM regulations No. 8 and 9 of 2006 regarding the construction of worship houses, the party proposed that PBM regulations No. 9 and 8 be revised. Those who stand in the line of proponents were Musdah Mulia from the ICRP (Indonesian Conference on Religion and Peace) Foundation. PGI (Communion of Churches in Indonesia) also expressed a similar view. The Setara Institute considers it to be revoked because "it stops minority groups from obtaining the right to worship". On the other hand, FKUB considers the regulation to be a Presidential Regulation. If needed, the regulation can be refined, and it does not need to be revoked.

While the PBM regulations No. 9 and 8 of 2006 as a development approach cannot fully solve the problem of building houses of worship, there is room for local wisdom to take it as cultural capital in solving problems related to houses of worship. Such practice can be observed in establishing houses of worship based on local wisdom in several areas in Eastern Indonesia or Kawasan Timur Indonesia (KTI). Not only approving, the house of worship even involves the active participation of adherents of other religions.

Research on the best practice of building houses based on local wisdom in KTI is crucial. This research tries to bring out the best facts about the construction of houses of worship where local wisdom plays an optimal role. One of the selected areas in KTI is Kendari City, Southeast Sulawesi. Kendari city was chosen as the location based on the consideration that Kendari City is a heterogeneous city in religion and ethnicity, moreover, it has a strong level of tolerance (Abas \& Haq, 2016). This research is also an effort to support the project of mainstreaming religious moderation, a major agenda of the Indonesian Ministry of Religion (Ministry of Religion of the Republic of Indonesia, 2019).

The main problem in this study is what are the best practices for building houses of worship based on local wisdom in Kendari City? This problem is divided into three subproblems: (1) what is the description of the best practice for the construction of the house of worship (2) how does local wisdom work optimally in the construction of the house of worship? (3) How is the participation of various elements of society related to houses of worship based on local wisdom development?

In this research, best practice is developing innovative ways, bringing about significant changes and results, being a sustainable solution to problems, and being a model and inspiration because the method and mechanism of its implementation reap optimal results (Apandi, 2019). Local wisdom refers to various cultural treasures that grow and develop in a community that is known, trusted, and recognized as an important element that can strengthen social cohesion in society (Haba, 2007). Local wisdom as the basis for best practice in building houses of worship in this study is conventions in values, norms, mechanisms, and active participation with various elements in a community.

In short, the best practices for building houses of worship based on local wisdom here are the best practices in constructing houses of worship carried out with a cultural approach and by optimally functioning local wisdom in solving problems related to the development.

\section{Literature Review}

Researchers and academics have carried out several studies and research related to places of worship in Indonesia. Anik Farida researched the establishment of churches in Bandung City after enacting PBM No. 9 and 8 of 2006. These results indicate that communication between elements involved in 
the establishment of houses of worship, as well as a well-running socialization process, are important factors for the success of the construction of houses of worship, although in a place where religious people who use the synagogue are a minority (Farida, 2017).

The Research Team of the Makassar Religious Research and Development Agency has also conducted a similar study. Saprillah researched the construction of houses of worship after PBM No. 9 and 8 of 2006 in Samarinda City (Saprillah, 2015). Sabara researched a similar case in North Sulawesi. He found, although the construction of houses of worship in North Sulawesi experienced rapid development after the enactment of the regulation, resistance to the construction of places of worship for Muslims still occurred in a number of areas there (Sabara, 2018). Cahyo Pamungkas found a case of difficulty for Muslim and Christian minority groups to establish places of worship in Bali, even though they had met the administrative requirements. This, according to his findings, is due to local government policies to protect Hindu identity and traditions, which are the main identity of Balinese people (Pamungkas, 2014).

Muhammad Ali Saputra also found the game of identity politics by the main group as an excuse to hinder the construction of one of the mosques in Manokwari City (Saputra, 2017). This study tries to identify the construction of places of worship based on local wisdom as the best practice by taking the case of the construction of the Anduonohu Stasi of Catholic Church in Kendari City.

\section{RESEARCH METHOD}

This research is descriptive qualitative that explained social phenomena about the best practice of building houses of worship in a community based on local wisdom (Moleong, 2012). A case study was used as the approach (Nawawi, 2003) to explore the contribution of local wisdom as best practice in constructing houses of worship.

In the data collection process, first, a case of the construction of a house of worship was selected based on local wisdom as the object of research. During the study, three methods were used in data collection, which were in-depth interviews, observations, and document studies, both written and images or videos (if available). Besides being used to gather information about the practice of building houses of worship based on local wisdom, interviews were also used to determine the next informant. Interviews were conducted with the related committee to construct houses of worship, religious and community leaders, the local Ministry of Religion, FKUB administrators, and other parties deemed able to provide the necessary information.

The researcher observed the place of worship under study and the surrounding environment, and the relationship between residents in the environment. The document study analyzed the recorded related events that have passed in writing, pictures, and videos (Sugiyono, 2007). Documentation studies were also used to track secondary data in the research, such as geographic and demographic data from BPS Kendari.

The data obtained from interviews, observations, and document reviews were processed using qualitative data analysis techniques. As proposed by Miles \& Huberman (Miles \& Huberman, 1996), the data analysis technique includes three stages: data condensation, data display or presentation, and drawing conclusions.

The research was conducted in two stages. The first stage was a field assessment for seven days in February 2021. The next stage was the dat a collection stage for 15 days and took place in March. The research was located in Kendari City, precisely in Anduonohu Village, Kec. Poasia. The place of worship chosen was the Anduonohu Stasi Church. The church was chosen because of the actual construction process and its location in an environment where the majority of the population is Muslim and is directly adjacent to a mosque built relatively at the same time as the construction of the church.

\section{DISCUSSION}

Kendari City, the capital of Southeast Sulawesi Province, is astronomically located in the southern part of the equator between 3054'40" and 405'05" South Latitude and stretches from West to East between 122026'33" and 122o39'14" East Longitude.

Based on its geographical position, Kendari City has the following boundaries: 
North - Konawe Regency; East - Kendari Sea; South - South Konawe Regency; West - South Konawe Regency.

The land area of Kendari City is $271.76 \mathrm{~km} 2$, or 0.7 percent of the land area of Southeast Sulawesi Province. The area, according to the district, is very diverse. Baruga District is the largest sub-district (18.18\%) of the Kendari City area, then Puuwatu District (16.01\%), Poasia District (15.79\%), Nambo District (9.32\%), Kambu District (8.13\%), Mandonga District (8.00\%), West Kendari District (7.77\%), Kendari District (5.33\%), Abeli District (5.12\%), Wua-Wua District (3, 97\%), and Kadia District (2.38\%).

The population of Kendari City consists of two. Indigenous people, namely residents of the Tolaki ethnicity and migrants/immigrants. Many of these migrants came from South Sulawesi and islands in Southeast Sulawesi, such as Buton and Muna. They leave their homeland for a better life. Many migrants from South Sulawesi are active in the small and medium economic sector, while some work in the government and education sectors. Migrants from Muna generally work in the agricultural sector as farmers. They are known as hardworking residents. They do not hesitate to do menial jobs such as port porters and are very concerned about education. Historically, Kendari City itself is the ancestral territory of the Tolaki people (Ministry of Education and Culture, 1984).

\section{Religious Social Conditions}

Sociologically, Kendari City is inhabited by residents who are predominantly Muslim. The statistics can be seen in Table 1 below (BPS, 2020).

Tabel 1. Number of Religious Adherents per District in Kendari City, 2019 (Kendari in Numbers 2020)

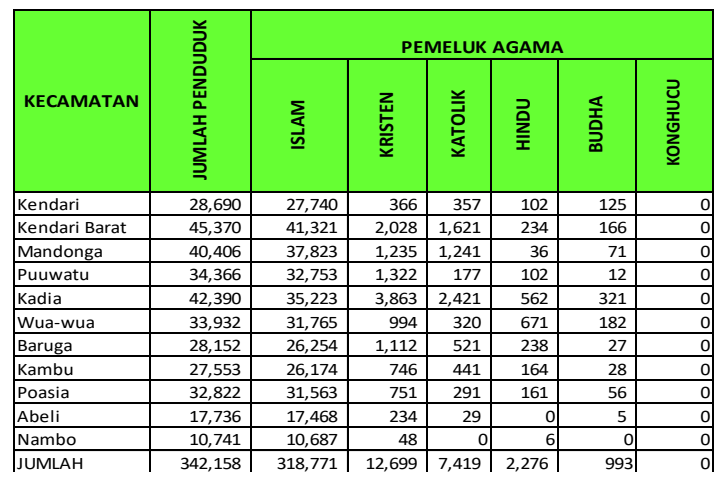

It can be seen in the table, from the 342,158 population of Kendari City recorded in 2019, 18,771 people are Muslim, followed by Christians, 12,699 people. Those who have not been recorded are Confucians, even though there is a Chinese community in Kendari. Kendari residents are generally residents (Tolaki) and migrants from several areas, mainly from South Sulawesi (BugisMakassar ethnicity) and from Buton and Muna islands, which are traditionally Muslim, so it is not surprising that the Muslim population in Kendari City is the most dominant. The next largest religious adherents are Christians and Catholics. They are dominated by immigrants from Toraja, Java, Ambon, Flores/Timor, and Tolaki residents.

In general, in Kendari City, interreligious harmony is well established. There are many places of worship located side by side/adjacent, between the mosque and the church. For example, the Da'wah Wanita Mosque and the Bukit Zaitun Pentecostal Church in Dapu-Dapura Village, Kendari District, are close to each other. The two houses of worship, built-in 1950, are still standing strong, even being updated, as more congregations carry out their daily religious rituals. A half-meter wall only separates the two buildings. Then the Akbar Mosque, the Immanuel Church on the Benu-Benua, the Al Muqarabun Mosque, the Jesus Gembala Church opposite Saranani Street, and the Majid Raya Al-Kautsar which is next to the Et-Labora Mandonga church.

Although Kendari residents consist of various religious adherents, the interaction and harmony between them remain harmonious. There are no records of interreligious conflicts in this city. Minority residents who are not Muslims, including Christians, Catholics, Hindus, and Buddhists, are free to carry out worship activities in their respective homes. In 2012, an incident damaged one of the temples in Kendari, namely the Penataran Agung Jagadhita Temple. The perpetrators damaged valuables and facilities in the temple. The results of the police investigation showed that this incident was pure criminal. The motive was the theft of money.

After enacting the Joint Ministerial Regulation (PBM) No. 9 and 8 of 2006, the construction of places of worship in Kendari City remains vibrant. Several non-Muslim 
places of worship are still being built. The following is data on houses of worship in Kendari in table 2 below.

Tabel 2. Number of Religious Adherents per District in Kendari City, 2019 (Kendari in Numbers 2020)

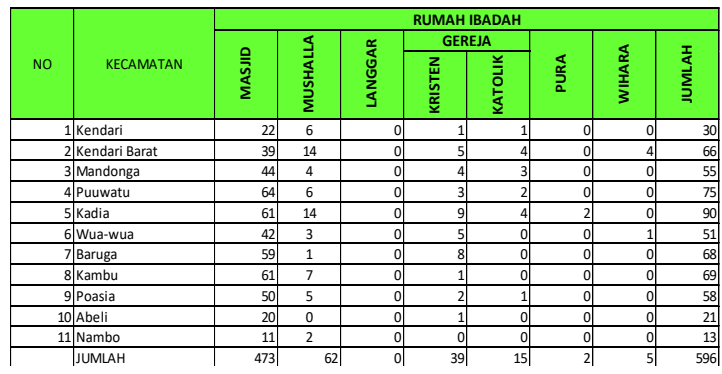

Officially, there has never been an obstacle that has prevented the construction of a place of worship in Kendari. However, several parties rejected the construction of a church in Kendari City in particular cases. The case is the construction of the Mepokoaso Church in 2011, which at the laying of the first stone, a few residents around the church environment was demonstrated, led by a resident figure from the Tolaki and the Bugis ethnicity. The church, located in the Punggolaka sub-district, Puuwatu subdistrict, has received 100 signatures and ID cards from residents, more than those required by PBM (90). It has also obtained a Building Construction Permit (IMB) from the Kendari City Government. The church has also held several meetings with the dissidents at the Punggolaka Sub-District Office, mediated by the village head, although they were deadlocked. After the Mayor of Kendari stepped in and immediately took part in laying the first stone for the church's construction, the protests stopped immediately. The workers resumed the construction process, although, at one time or another, they received verbal intimidation from a resident, the son of one of the local leaders who refused to build the church.

A case of residents' rejection of the construction of non-Muslim houses of worship was also reported in one district in Southeast Sulawesi. Precisely in North Kolaka Regency. In this area, according to an informant from the church community, the attitude of residents who are predominantly Muslim does not agree with the existence of a permanent church there. Church buildings are generally semi/non-permanent, while the church's intention to build a larger/permanent church building is always opposed by residents, even though the regent has expressed his approval and is even ready to distribute aid for the construction of the church. There are also stories of the failure of the plan to build a church on land purchased but was opposed by residents. In the end, the land was forced to be sold again by the church. What is even riskier is that at one time, people who were Christians got a stone throw from residents just because they played tapes of spiritual songs at their homes. This may have something to do with the history of North Kolaka, which was the base of operations for the DI/TII Movement in the Southeast Sulawesi Region in the 1950s, which can form a culture of the fanaticism of citizens who are predominantly Muslim even though the government can suppress the subversion movement.

In addition to the problem of building a church, as mentioned earlier, there are also a few obstacles encountered by Hindu residents who live in one area on the island of Buton. According to information from research informants, every year, Hindus who worship at the temple usually use loudspeakers such as toa every time they participate in routine ritual activities. Muslim residents who live around Hindu settlements do not mind this. However, recently, these residents no longer allow Hindus to use these tools when worshiping in temples. This change in attitude, according to the informant, occurred after a preacher who often preached and gave lectures in the village often preach religious content that tends to be intolerant to the villagers. In turn, these religious lectures with intolerant nuances allegedly changed the residents' attitude towards the Hindus.

One of the administrators of the Kendari City FKUB is of the view that the obstacles to the construction of several churches in the Southeast Sulawesi region generally stem from the lack of socialization of the worship site's construction to residents around the church. He gave an example of the construction of the Hebron Church in the Baruga sub-district, Kendari City. "There are several places of worship/churches whose construction has not been implemented because the surrounding community has not agreed. After I searched the surrounding residents, it turned out that the church 
management was not proactive in approaching residents from their information. So, the drawback is the problem of socialization. This can be seen in the case of the Hebron Kendari Church. The church is still a non-permanent building from the plank and has long applied for a permit to build a permanent church. However, the church has never had a citizen's signature or ID card as proof of approval and one of the requirements for obtaining a construction permit. If only the church were pro-active, they could easily build their church."

Even so, the construction of the Hebron Church is still "right on the track". This was conveyed by an administrator of the Galilee Church, Gep North Sulawesi. Until now, the Hebron Church construction committee is still busy gathering evidence of residents' approval. He is optimistic that the construction of the church will go peacefully.

\section{History of the Anduonouhu Stasi of Catholic Curch}

The Catholic Church of Santa Maria Diangkat Ke Surga, Anduonohu Paroki Santo Fransiskus Xaverius KAMS Stasi, located in Anduonohu village, Poasia sub-district, has existed since the 1980s. At that time, Pastor Isodorus together with a congregation, Donat us Renyan held a service at the house of Mr. Donatus Renyan in Anduonohu village. Around 1992, a non-permanent church began to be built at that location with a building area of approximately $6 \times 10 \mathrm{~m}^{2}$. The church building has red stone walls, boards, and a tin roof, with wooden pillars. The church was built on land granted by a congregation named Yohannes Ari, who bought the land from a resident. With the existence of this board church, Catholic residents who are members of the church can still serve six families. However, worship activities at that time could not be carried out every week because of difficulties accessing the site. At that time, the road around the location was not as good as it is now. There was only one access road to get there that could only be passed by one car. No bypass roads or bridges were connecting Kendari City to Anduonohu at that time.

As time went by, the church welcomed a pastor, namely Martinus Pasumba. He was with one of our informants, a church member who came to Kendari in 1995 and worked in a private company in
Kendari to start building their church in a permanent building. The main reason is the condition of the church building, which is old and obsolete, so it is not suitable for safe worship. On the other hand, the number of church congregations was projected to grow along with the rapid development of Kendari City. The church has even obtained a building construction permit (IMB) which the Mayor of Kendari signed on September 14, 2007.

Problems arose when the construction of a permanent church began with the construction of the foundation, precisely in 2011. A Muslim resident who lives in front of the church construction site sent a sue about the ownership of the church land. The resident claimed to be the legal heir of the previous landowner who sold it to Mr. Yohannes Ari, even though the land had already been certified. Through the research informant, the church initially met with the prosecutor to seek an amicable solution to the case of the church land claim. The church asked the prosecutor not to file a lawsuit in court to avoid any possible social impact, although later, the church won the ownership because they were in a stronger position. Some compensations were offered (worth Rp 80 million) but were rejected by the prosecutor, who received support from local NGOs. The amicable settlement failed, and the case continued to the Administrative Court.

The lawsuit was rejected in the Administrative Court. Defeated in the Kendari Administrative Court, the prosecutor continued his lawsuit to the Makassar Administrative Court, ending in the prosecutor's defeat. Still curious, the prosecutor's defeat. He filed his lawsuit again, and this time went to the district court. The judge in charge suggested that this lawsuit be resolved through mediation only. The church accepted this suggestion but put forward a condition that all of the prosecutor's younger siblings be signed, arguing that the prosecutor was the one who started the problem. For this mediation process, the church offered compensation. According to Mr. Tikno as the church's representative in these cases, avoid filing a lawsuit to a higher court level until a cassation because it will take up to nine years, with a much larger budget. The plaintiff approved the compensation offered through mediation, and the church land dispute was deemed resolved. 
After the construction phase of the church foundation was completed, the construction committee did not immediately build the church building but chose to build a fence around the church. This was to anticipate the emergence of any possible problem after the case of land ownership claims. Luckily, the new suit never appeared. The construction of the Anduonohu Stasi of Catholic Church was obtained from the church congregation's self-help and assistance from some parties and sponsors, such as the Catholic Guidance of the Ministry of Religion of the Republic Indonesia, BNI Bank, and relational partners. During the construction period of the new building, worship activities continued to be carried out in the existing plank church on the church's land. The old building was only demolished in mid-2020 and used as part of the church parking lot.

Currently, the construction of the new church is almost complete. One interesting thing, the Anduonohu Stasi of Catholic Church is located with the Nurul Khair Mosque. The two places of worship are only separated by a house at the front and the church wall next to the mosque. Both began to be built at about the same time. Although the Anduonohu Stasi of Catholic Church is located in a residential area dominated by Muslims. Its presence is older than its neighboring mosque. The Catholic church has existed since 1990, although at that time the building was still in the form of a plank. In comparison, the new mosque was built around 2011, almost simultaneously with the construction of the church foundation.

\section{Best Practices of Church Building}

Anticipating complications that could potentially arise in the community in constructing houses of worship, the government issued regulations. Based on the Joint Regulation of the Minister of Religion No. 9 and 8 of 2006, every construction of worship in Indonesia must meet certain requirements. This regulation regulates the establishment of houses of worship and regulates the duties and policies of local governments, both provincial and district/city, to build religious harmony in the region (Ismardi, 2011). The establishment of houses of worship in this regulation is stated in a separate article, namely Articles 13 to 20 . In Article 14, there are several points: (1) based on the composition of the population for religious services in the area concerned. (2) if this is not achieved, then the consideration may be based on the composition of the population according to the boundaries of the sub-district or district/city, (3) must meet the administrative and technical requirements of the building, and (4) meet the special requirements, including names and ID cards of at least 90 people who use houses of worship legalized by local officials in accordance with the level of the aforementioned territorial boundaries and get the support of the local community at least 60 people who are legalized by the local headman/village head, and (5) written recommendation from the Head of the Office Ministry of Religion and FKUB of Regency/City.

In connection with the establishment of the Anduonohu Stasi of Catholic Church, the church's construction, although it is a new building, is a continuation of the old plank church building. When the old church was built in 1992, PBM did not yet exist. At that time, the establishment of houses of worship still referred to the old regulations, namely the Decree of the Minister of Home Affairs and the Minister of Religion No.1 of 1969 in Article 4:

1) Every establishment of a house of worship needs to obtain a permit from the Regional Head or a government official under him who is authorized.

2) The Regional Head or the official referred to in paragraph (1) of this article shall grant the said permit after considering (a) the opinion of the Head of the local Representative of the Ministry of Religion, (b) planology, (c) local conditions and circumstances.

3) If necessary, the Regional Head or the appointed official may seek opinions from local religious organizations and clerics/spiritualists.

Referring to these regulations, the establishment of the Anduonohu Stasi of Catholic Church, which was not permanent, was based on a permit granted by the Mayor of Kendari as the Regional Head. Communication with residents is also maintained. Residents accepted the church's existence, and not during its operational period until the old building was torn down to rebuild a new one, there were no dist urbances 
from the surroundings. There were complaints from residents during the construction of the new church building, which is in the foundation construction phase. However, this only relates to civil matters, the ownership of church land. This is not related to the disagreement of the residents to the church construction.

According to an informant who lives near the church site, the lawsuit seems to be driven by economic motives. The skyrocketing land price in Kendari, including at the church site, allegedly prompted the residents to file a lawsuit, even though the church already had a certificate of title to the land. In addition, the church construction committee has also obtained an IMB. Apart from the prosecutor, no other residents around the church joined the prosecutor's side.

\section{Contribution of Local Wisdom}

The city of Kendari, the Anduonohu village, and the location around the church are inhabited by multi-ethnic and multi-religious people. There are various tribes with their respective values and cultures living side by side peacefully. Historically, Kendari City is a Tolaki ethnic area. With so many immigrants, local ethnic groups mingle with the newcomers. One of the immigrant tribes, but still in the Southeast Sulawesi area who also lives in Kendari, is the Muna Tribe. These residents of the Muna Tribe were the first to inhabit the neighborhood around the Anduonohu Stasi of Catholic Church. The beginning of their arrival was around the 1980s. These residents, generally working as porters at the port in the Old Town of Kendari, were given land by the local government in the Anduonohu neighborhood, which is now the church's location. Gradually, residents from other ethnic groups arrived, such as Bugis Makassar, Buton, Flores, Javanese, and Toraja. Ethnic residents of Muna, Bugis Makassar, Buton, parts of Java are generally Muslim, while ethnic Flores and Toraja are generally Christian/Catholic. The residents, both early immigrants, namely the Muna ethnicity, and from other ethnic groups, also live mingling and neighbors, without any barriers. There are no pockets of settlement for Muna or other immigrants who stand alone. On ordinary days, on religious holidays, people from different religions also visit each other and stay in touch.
Every Eid day, residents from Flores and Toraja and other non-Muslim residents come to visit Muslim residents and enjoy the host's meal. While every Christmas celebration, Muslim residents will visit and stay in touch with their Christian/Catholic neighbors. Residents next to the church are generally residents of Muna origin. Some are from other ethnicities, although not as much as the Muna ethnic group. Many factors are behind this open attitude that causes residents of different ethnicities and religions to live in harmony and peace. One of those is currently widely referred to as a supporter of tolerance is local wisdom.

Why residents (Muna) who are Muslims want to sell their land to Catholics and give it up to be used as a place of worship for Catholics and why residents of a neighborhood in Anduonohu Kendari village, which is predominantly Muslim, allow the construction of a church in the middle of their settlement are interesting questions. Is there so-called living local wisdom that contributes to this attitude of tolerance? Related to this, Sabara reviews local wisdom that is potential to maintain harmony on Muna Island. The local wisdom is gampola or cooperation culture, Modure and Linda dances, as well as wise messages from Kabali such as Dapo Moa Moa Sioho (love one another), Dapo Angka Angkatau (respect each other), Dapo Mo Moologho (help each other), Dapo Adha Adhati (mutual respect for one another), and Dapo Pia Piara/Dapo Bhinibhini Kuli (honoring each other, loving each other, nurturing each other, being considerate of each other) (Sabara, 2015).

If the church is holding worship activities on Sundays, the chairman of the Takmir of the Nurul Khair Mosque instructs muezzins not to use the loudspeaker during the call to prayer and not to play recitation tapes when it is time for prayer. On the other hand, when Muslims are performing the evening prayers in the mosque, and the church is holding worship, the church administrators will not sing hymns or play musical instruments in the church. When Catholics celebrate Christmas at the church, the mosque administrator offers church congregants whose vehicles are not accommodated in the church parking lot to park in the mosque yard or around the mosque. 


\section{Participation of Community and Government Elements}

In the construction of the Anduonohu Stasi of Catholic Church, the church itself took a big role. The church building committee collects funds and donations, both in money and materials from donors. They also provide the carpenters to build. Meanwhile, the surrounding community (except church members) were not involved in the development process, either providing financial contributions or involving themselves. All materials for the construction of the church are stored in the church's vast land. Uniquely, at the time of construction, the church did not hesitate to assist the surrounding Muslim residents. For example, when a Muslim resident whose house is right in front of the church needs sand to build his house and asks Mr. T if he can use the sand on the church's land, Mr. T welcomes him. Vice versa, when the church needed a building material, the chairman of the mosque takmir invited Mr. T to use it to construct the church.

The role of the government can be stated as follows. The government gave recommendations and permits to the construction committee of the Anduonohu Stasi of Catholic Church to build. In addition, through the Catholic Guidance of the Ministry of Religion, the government channeled its assistance to the church building committee.

\section{RESEARCH LIMITATION}

Although this research was carried out through the stages of scoping and data collection for a total of 22 days, it started to find the appropriate focus of research objects only a few days before the end of the data collection period. The object of the initial research, which was the construction of the Mepokoaso Kendari church. After the data collection took more than a week, the researcher was forced to decide not to continue/explore until it was completed because the data obtained was deemed not to have reached the goal of this research, which is the best practice of houses of worship building based on local wisdom.

The main reason was the construction process gained protests from some residents around the church environment who did not agree with the church's construction. Mediation carried out at the District Office between the church building committee and the residents who were against it failed to have an agreement, although it was carried out several times. Only intervention from the government, the mayor of Kendari, ensured the continuation of the construction of the church until it was completed. This settlement was seen as not showing the resolution of conflicts in constructing houses of worship based on local wisdom. Therefore, the data and sources that researchers can explore regarding the construction of the Anduonohu Stasi of Catholic church as the focus of this research's object as well as the potential of local wisdom of the surrounding residents, which is the basis for it. In the period of data collection remaining in the field, such situation has not been considered maximal/final as expected by researcher and is still need to be explored further.

\section{CLOSING}

The construction of the Anduonohu Stasi of Catholic Church proceeded peacefully. The church can fulfill the administrative requirements according to applicable regulations (the Church's IMB was issued in 2007). There is no rejection from residents who are predominantly Muslim. A lawsuit from a citizen is more a civil matter, namely ownership rights, not because of religious differences.

In the construction of the church, although it was not explicitly stated that it was based on local wisdom, the construction of the Catholic Church in Anduonohu was supported by the values/sense of responsibility, mutual respect, and love, as well as the willingness to sacrifice as shown by the residents around the church and other parties and the church itself.

The community around the church did not participate in providing financial or labor material assistance. However, their willingness to accept a different place of worship in their environment is shown by not making efforts to reject it. Meanwhile, from the government side, participation takes the form of granting permits and recommendations, and distributing aid. 


\section{ACKNOWLEDGEMENT}

The author would like to thank Dr. H. Saprillah, M.Si, head of Office of Balai Litbang Agama Makassar, for granting me the opportunity to be involved in the 2021 research program and for any participants in this research for their cooperation during my stay in Palopo.

\section{REFERENCES}

Abas, Muh., \& Haq, Pendais. 2016. "Indeks Kerukunan Umat Beragama di Kota Kendari Ditinjau dari Aspek Hubungan Sosial, Hubungan Keagamaan, nilai, dan Peran Pemerintah". Historical Education Jurnal Penelitian Pendidikan Sejarah Vol. 1 No 1 April.

Apandi, Idris. 2019. Kiat Praktis Menulis Best Practice. Ciamis: Tsaqiya Publishing.

BPS. Kota Kendari Dalam Angka 2020.

Depdikbud. 1984. Sejarah Sosial Sulawesi Tenggara. Jakarta: Direktorat Sejarah dan Nilai Tradisional.

Farida, Anik. 2017. "Pendirian Rumah Ibadat Pasca PBM No 9 dan 8 Tahun 2006 dan Kerukunan Umat Beragama: Kasus Pendirian Gereja di Kota Bandung, Jawa Barat". Harmoni Jurnal Multikultural dan Multi Religius Vol. 16 No. 2 Juli-Desember.

Haba, John. 2007. Revitalisasi Kearifan Lokal: studi resolusi Konflik di Kalimantan Barat, maluku, dan Poso. Jakarta: ICIP \& European Commission.

Ismardi. 2011. "Pendirian Rumah Ibadat Menurut Peraturan Bersama Menteri Agama dan Menteri Dalam Negeri No. 9 dan 8 Tahun 2006". Toleransi: Media Ilmiah Komunikasi Vol. 3 No 2 JuliDesember.

Kementerian Agama RI. 2019. Moderasi Beragama. Jakarta: Badan Litbang dan Diklat Kementerian Agama RI.
Madrim, Sasmita. 2020. Komnas HAM Temukan 23 Kasus Rumah Ibadah Sepanjang 3 Tahun Terakhir. VOA Indonesia.

https://www.voaindonesia.com/a/komn as-ham-temukan-23-kasus-rumahibadah-sepanjang-3-tahunterakhir/5650714.html. Diakses tanggal 15 Mei 2021 Pukul 19.17 WITA.

Miles, M.B., Huberman, A.M. 1996. Analisis Data Kualitatif. Jakarta: Universitas Indonesia Press.

Moleong, Rexy J. 2012. Metodologi Penelitian Kualitatif Edisi Revisi. Cet. XXX. Bandung: Remaja Rosdakarya.

Nawawi, Hadari. 2003. Metode Penelitian Sosial. Yogyakarta: Gadjah Mada University Press.

Pamungkas, Cahyo. 2014. "Toleransi Beragama Dalam Praktek Sosial: Studi Kasus Mayoritas dan Minoritas Agama di Kabupaten Buleleng”. Episteme Vol. 9 No 2 Desember.

Sabara. 2015. "Merawat Kerukunan dengan Kearifan Lokal di Kabupaten Muna Sulawesi Tenggara". Jurnal Al-Qalam Vol. 21 No. 2 Desember.

Sabara. 2018. “". Harmoni Jurnal Multikultural dan Multireligius Vol. 17 No. 1 Januari-Juni.

Saprillah. 2015. "Pembangunan Rumah Ibadat Pasca PBM No. 9 dan 8 Tahun 2006 di Kota Samarinda". Dilema Pembangunan Rumah Ibadat, Ed. Darlis. Yogtakarta: Ladang Kata.

Saputra, Muh. Ali. 2017. "Menguatnya Politik Identitas dan Problem Kerukunan Beragama di Manokwari”. Mimikri Vol. 3 No.1.

Sugiyono. 2007. Metode Penelitian Pendidikan Kuantitatif, Kualitatif, dan $R \& D$. Jakarta: Alfabeta. 